\title{
Malignant eosinophilic ascites due to metastatic urothelial carcinoma with peritoneal carcinomatosis
}

\author{
Michael Carranza, ${ }^{1}$ Michael Chahin (10, ${ }^{1}$ Anwer Siddiqi, ${ }^{2}$ Jeff House ${ }^{1}$
}

${ }^{1}$ Internal Medicine, University of Florida College of MedicineJacksonville, Jacksonville, Florida, USA

${ }^{2}$ Pathology and Laboratory Medicine, University of Florida College of MedicineJacksonville, Jacksonville, Florida, USA

\section{Correspondence to} Dr Michael Carranza; michael.carranza@jax.ufl.edu

Accepted 8 November 2020

\section{DESCRIPTION}

A 59-year-old man with a history of tobacco use presented for worsening abdominal pain and swelling associated with weight loss and haematuria. Physical examination revealed a thin-appearing man with tense ascites and a palpable mass in the right lower quadrant. Initial laboratory studies revealed a neutrophil-predominant leucocytosis of $27.64 \times$ $10^{3} / \mu \mathrm{L}$ with an absolute eosinophil count of 4.05 $\times 10^{3} / \mu \mathrm{L}$. CT of the abdomen and pelvis showed nodular thickening of the bladder wall and diffuse peritoneal carcinomatosis with large volume ascites.

A paracentesis was performed, revealing an ascitic fluid containing 1746 leucocytes/ $\mu \mathrm{L}$, of which $40 \%$ were eosinophils. Notably, the serumascites albumin gradient was $<1.1 \mathrm{~g} / \mathrm{dL}$, the ascitic protein $>3.5 \mathrm{~g} / \mathrm{dL}$, and cytology positive for malignant urothelial cells (figure 1). Diagnostic evaluations for bacterial peritonitis, tuberculosis, parasitic infection, urinary ascites due to bladder perforation and other haematological disorders were unrevealing. Specifically, serum antibody testing for Strongyloides and Toxocara, interferon-y release assay and ascitic fluid adenosine deaminase, and flow cytometry were negative. There were no clinical or imaging findings to suggest hydatid cyst rupture, chronic pancreatitis, vasculitis or Crohn's Disease. Transurethral resection of bladder tumour revealed a poorly differentiated plasmacytoid variant of urothelial carcinoma with deep muscle invasion surrounded by eosinophils (figure 2). Our patient was later discharged with plans to follow-up with oncology, but he presented to the hospital

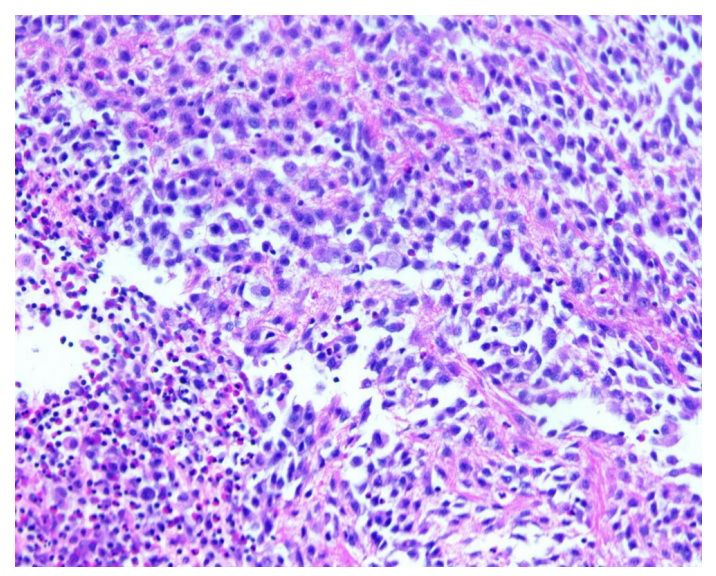

Figure 1 Ascitic fluid cell block section showing discohesive plasmacytoid urothelial tumour cells with abundant cytoplasm, eccentric nuclei and inconspicuous nucleoli. The surrounding stroma appears loose and many accompanying eosinophils are also noted (H\&E 10x).

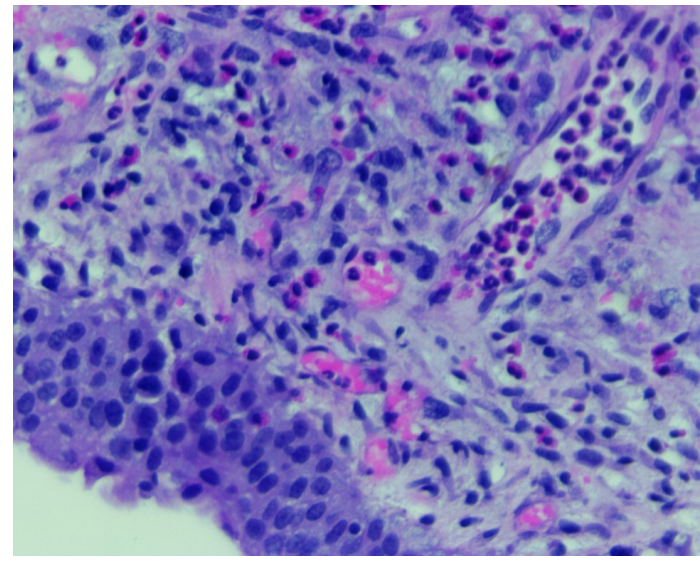

Figure 2 Bladder biopsy with dysplastic surface urothelial lining and tumour cells within lamina propria surrounded by eosinophils (H\&E 20x).

several days later with rapidly accumulating ascites, requiring placement of a palliative peritoneal catheter. He ultimately opted for hospice care.

Malignant eosinophilic ascites in the setting of urothelial carcinoma with extensive peritoneal carcinomatosis is an exceedingly rare clinical scenario that, to our knowledge, has not been previously reported. Malignant ascites is facilitated by increased vascular permeability due to peritoneal carcinomatosis, portal hypertension due to massive liver metastasis or cirrhosis, or lymphatic channel disruption. ${ }^{12}$ The ascitic fluid profile in our case was classic for peritoneal carcinomatosis without massive liver metastasis. ${ }^{13}$ While urothelial carcinoma uncommonly leads to peritoneal carcinomatosis and ascites, accounting for approximately 1\% of all cases of malignant ascites, the plasmacytoid variant may have a proclivity for both. ${ }^{45}$ However, cellular differentials of the ascitic fluid are often incompletely reported or omitted, and none are detailed as eosinophilic. Eosinophilic ascites itself has a wide differential diagnosis, requiring scrutiny for both benign and malignant conditions. ${ }^{67}$ Our patient's pathological diagnosis of poorly differentiated plasmacytoid variant of urothelial carcinoma likely explains the clinical findings of diffuse peritoneal involvement and rapidly accumulating ascites.

It is possible that the eosinophilic ascites in our case was facilitated by the tumour-associated tissue eosinophilia surrounding the malignant cells in the ascitic fluid and bladder biopsy specimens. Eosinophils are thought to have antitumour effects and are often present within tumours. In some cases, the presence of eosinophils has shown a favourable outcome, in others a worse, and in bladder cancer 
there may be no difference at all. ${ }^{8}$ While malignant eosinophilic ascites is rarely encountered, our case implicates urothelial carcinoma with peritoneal carcinomatosis as a newly recognised cause that clinicians should consider.

\section{Learning points}

- Ascitic eosinophilia may be due to entities such tuberculosis, parasitic infections and hypereosinophilic syndromes. However, malignancy should also be considered.

- Eosinophilia often occurs at the sites of tumour cells, known as tumor-associated tissue eosinophilia, but the overall effect remains unclear.

- The likely mechanism of tumour-related eosinophilic ascites from carcinomatosis starts with increased vascular permeability and lymphatic obstruction. The eosinophils are then introduced into the ascites with the tumour cells.

Twitter Anwer Siddiqi @anwer.siddiqi@jax.ufl.edu

Contributors MCa and MCh wrote the main manuscript. AS provided the pathology slides and descriptions. JH reviewed and edited the manuscript.

Funding The authors have not declared a specific grant for this research from any funding agency in the public, commercial or not-for-profit sectors.
Competing interests None declared.

Patient consent for publication Obtained.

Provenance and peer review Not commissioned; externally peer reviewed.

\section{ORCID iD}

Michael Chahin http://orcid.org/0000-0001-9371-0252

\section{REFERENCES}

1 Runyon BA, Hoefs JC, Morgan TR. Ascitic fluid analysis in malignancy-related ascites. Hepatology 1988;8:1104-9

2 Sangisetty SL, Miner TJ. Malignant ascites: a review of prognostic factors, pathophysiology and therapeutic measures. World I Gastrointest Surg 2012;4:87-95.

3 Tarn AC, Lapworth R. Biochemical analysis of ascitic (peritoneal) fluid: what should we measure? Ann Clin Biochem 2010:47:397-407.

4 Raymond SLT, Au K, Fu R, et al. Metastatic genitourinary cancer diagnosed by body fluid cytology: clinicopathologic and cytomorphologic correlation. J Am Soc Cytopathol 2017;6:48-58.

5 Shao Y-H, Kao C-C, Tang S-H, et al. Unusual presentation of direct intraperitoneal metastases complicated with massive ascites from plasmacytoid variant of bladder cancer and adenocarcinoma of colon: a case report and literature review. Medicine 2017;96:e5816.

6 Khalil H, Joseph M. Eosinophilic ascites: a diagnostic challenge. BMJ Case Rep 2016;2016:bcr-2016-216791.

7 Pinte L, Baicuş C. Causes of eosinophilic ascites - A systematic review. Rom J Intern Med 2019:57:110-24

8 Varricchi G, Galdiero MR, Loffredo S, et al. Eosinophils: the unsung heroes in cancer? Oncoimmunology 2018;7:e1393134.

Copyright 2020 BMJ Publishing Group. All rights reserved. For permission to reuse any of this content visit

https://www.bmj.com/company/products-services/rights-and-licensing/permissions/

BMJ Case Report Fellows may re-use this article for personal use and teaching without any further permission.

Become a Fellow of BMJ Case Reports today and you can:

- Submit as many cases as you like

- Enjoy fast sympathetic peer review and rapid publication of accepted articles

- Access all the published articles

Re-use any of the published material for personal use and teaching without further permission

Customer Service

If you have any further queries about your subscription, please contact our customer services team on +44 (0) 2071111105 or via email at support@bmj.com.

Visit casereports.bmj.com for more articles like this and to become a Fellow 